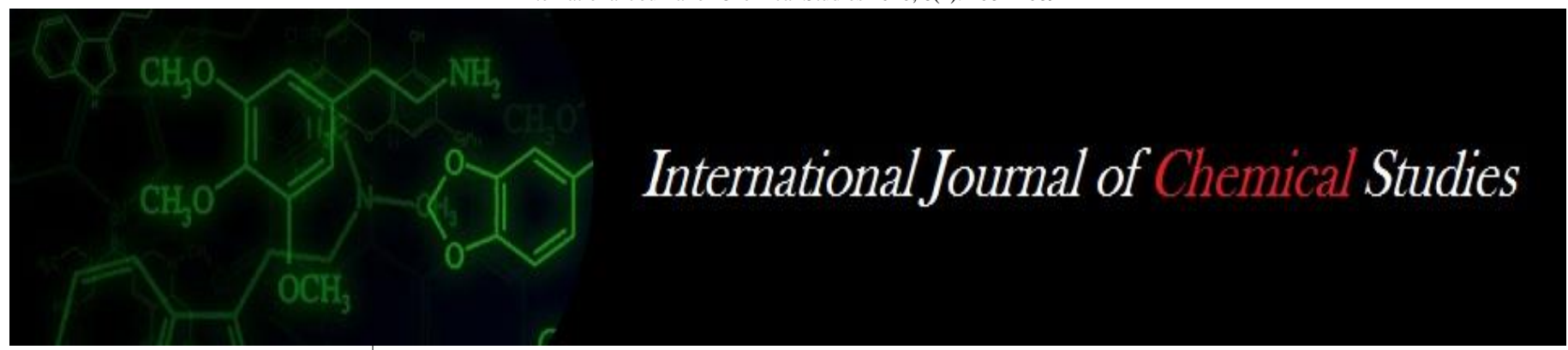

P-ISSN: 2349-8528

E-ISSN: 2321-4902

www.chemijournal.com

IJCS 2020; 8(2): 1082-1089

(C) 2020 IJCS

Received: 03-01-2020

Accepted: 06-02-2020

Pradeep Kumar Sahu

Department of Plantation,

Spices, Medicinal, and Aromatic

Crops K.N.K. College of

Horticulture Mandsaur,

RVSKVV, Madhya Pradesh,

India

IS Naruka

Department of Plantation,

Spices, Medicinal, and Aromatic

Crops K.N.K. College of

Horticulture Mandsaur,

RVSKVV, Madhya Pradesh,

India

\section{Ajay Haldar}

Department of Plantation,

Spices, Medicinal, and Aromatic

Crops K.N.K. College of

Horticulture Mandsaur,

RVSKVV, Madhya Pradesh,

India

\section{RS Chundawat}

Department of Plantation,

Spices, Medicinal, and Aromatic

Crops K.N.K. College of

Horticulture Mandsaur,

RVSKVV, Madhya Pradesh,

India

\section{Lalit Kumar}

Department of Plantation,

Spices, Medicinal, and Aromatic

Crops K.N.K. College of

Horticulture Mandsaur,

RVSKVV, Madhya Pradesh,

India

\section{Studies on the effects of integrated nutrient management on fenugreek (Trigonella foenum- graecum) L.}

\author{
Pradeep Kumar Sahu, IS Naruka, Ajay Haldar, RS Chundawat and Lalit \\ Kumar
}

DOI: https://doi.org/10.22271/chemi.2020.v8.i2q.8911

\section{Abstract}

The present investigation entitled "Studies the effect of integrated nutrient management on fenugreek (Trigonella foenum-graecum L.) "Was conducted during the period from October 2016 to March 2017 at the Department of Plantation, Spices, Medicinal, Aromatic Crops, College of Horticulture Mandsaur, Rajmata Vijayaraje Scindia Krishi Vishwa Vidyalaya Gwalior (M.P.) The experiment was laid out in Randomized Block Design with three replications. Fenugreek cultivar AFG-3 was used for the experiment. Twelve treatments consisting of integrated nutrient management with organic, inorganic and biofertilizers along with control.The observations on different growth and yield parameters were recorded and the results obtained are summarized below. On the basis of one year research trial it could be concluded that the treatment $\left(\mathrm{T}_{11}\right)$ i.e. $50 \% \mathrm{RDF}+$ Neem cake @ 1 ton ha ${ }^{-1}+$ Rhizobium + PSB was best at all the stages of growth parameters like plant height 30,60 and 90 das $(\mathrm{cm})$, number of primary branches per plant at 30,60 and 90 DAS, number of secondary branches per plant at 60 and 90 DAS, length of internode, days to $50 \%$ flowering, fresh and dry weight of the plants and yield parameters like days to first pod formation, days to $50 \%$ pod formation, number of pods per plant, weight of pod, pod length at number of seeds per pod, weight of seeds per pod, seed yield per plant, seed yield ( $\mathrm{q} \mathrm{ha}^{-1}$ ), harvest index and days taken to maturity showed better performance from other treatments of organic, inorganic and biofertilizers applications.

Keywords: Fenugreek, Neem cake, Rhizobium, PSB, INM, organic and inorganic fertilizers

\section{Introduction}

Fenugreek (Trigonella foenum-graecum L.), commonly called as 'Greek hay' and also called as 'methi' in Hindi. Fenugreek is an annual crop belonging to the family Fabaceae. The chromosome number is $2 \mathrm{n}$ $=16$. There are only two important species recognized common methi \& Kasuri methi.

It's an annual herb native to South-East Europe and West Asia. India is the largest producer of fenugreek with an area of 65,000 hectare and production of 90,000 MT. Major fenugreek growing states are Rajasthan, Punjab, Madhya Pradesh, Maharashtra, Uttar Pradesh and Gujarat.

Improper nutrient management is one of the factor responsible for the low productivity. Use of organic manures along with inorganic fertilizers not only improve physico-chemical and biological properties of soil but also provides all the nutrients in available form to crop plants, which in turn enhance better growth and finally the yield and quality parameters of Trigonella foenum-graecum. Thus, there is an urgent need to formulate integrated nutrient management practices for increasing the productivity and production of Trigonella foenum-graecum.

Keeping in view the above facts and the paucity of research on these aspects in the Malwa region of Madhya Pradesh

\section{Materials and Methods}

A field experiment was conducted on "Study the effect of integrated nutrient management of fenugreek (Trigonella foenum - graecum L.)"'at the Research farm College of Horticulture, Mandsaur, Rajmata Vijayaraje Scindia Krishi Vishwa Vidyalaya, Gwalior, (M.P.) from 2016 to 2017. The details of the materials used and methods followed during the course of investigation are presented in this chapter. The experiment was carried out at the "Research farm" College of Horticulture, Mandsaur, Rajmata Vijayraje Scindia Krishi Vishwa Vidyalaya, Gwalior, (M.P.) during 2016-17. The College of Horticulture, Mandsaur is situated in Malwa Plateau in Western part of Madhya Pradesh at 23.450 to 24.130 North Latitude, 74.440 to 75.180 East Longitudes and at an Altitude of 435.02 meters above mean sea level.
Corresponding Author:

Pradeep Kumar Sahu

Department of Plantation,

Spices, Medicinal, and Aromatic

Crops K.N.K. College of

Horticulture Mandsaur,

RVSKVV, Madhya Pradesh,

India 
This region falls under agro climate Zone No.10 State. To ascertain physico-chemical characteristics of the soil during the year of study, soil samples from $0-15 \mathrm{~cm}$ depth were taken from different spots of the experimental field before application of fertilizer. A representative composite sample was prepared by processing and mixing them together and analysis presented, showed that the soil of experimental site is light black loamy texture, with low in availability of nitrogen, low in phosphorus and high in potassium status. The experiment was laid out in open field with Randomized Block design. There were three replications in the experiment. The plan of layout of the experiment is given. Fenugreek $c v$. AFG3 (Ajmer Fenugreek-3) developed by National Research Centre on Seed Spices, Tabiji Ajmer (Rajasthan) has been taken for the experiment purpose. The experimental plot was ploughed twice by tractor drawn cultivator and leveled. The clods were crushed; weeds were removed and brought to fine tilth. The land was divided into plots of required size $(1.8 \mathrm{~m} \mathrm{x}$ $2.5 \mathrm{~m}$ ). Provision was made for bunds and irrigation channels. In inorganic fertilizer treatments $(50 \%, 75 \%$ and $100 \%$ Recommended Dose of Fertilizers) nitrogen, phosphorus and potassium nutrients were applied in the form of urea, single super phosphate and murate of potash respectively. Nitrogen was applied in two equal split doses i.e. $1 / 2$ basal and remaining dose at 20 days after sowing. The entire phosphorus and potassium were applied as basal. Vermicompost was obtained by culturing Eisenia foetida earthworms on farm waste along with fresh animal dung. Farm yard manure was obtained by composting different crop residues along with animal dung and only fully decomposed manure was used. Poultry droppings were collected from cage type of poultry units and allowed to decompose fully and the neem cake was obtained by crushing neem seed kernels and they are used in experimental plot. Biofertilizers, viz.,
Rhizobium meloloti and phosphate solubilizing bacteria (PSB) Bacillus megatherium were obtained from commercial formulations of PSB with colony forming unit (CFU) of $1 \mathrm{x}$ 108 were used. PSB @ $5 \mathrm{~kg}$ ha-1 was inoculated with the respective organic manures and thoroughly incorporated into soil one week before sowing of the crop. After $24 \mathrm{hrs}$ of the bavistin treatment to the seed, Rhizobium culture was applied to the seed. The Rhizobium culture @ 500g inoculant mixed in sugar syrup and applied to the fenugreek seed (25 kg ha-1) by slurry method. The seeds were soaked overnight and they were treated with Captan $2 \mathrm{~g} / \mathrm{kg}$ seeds. Later they were shade dried for half an hour. The seeds were used with the seed rate of $22-25 \mathrm{~kg} / \mathrm{ha}$ and $2-3$ seeds were sown per hole. Seeds were sown on October 17, 2016 at spacing with varieties. Furrows were properly covered with a thin layer of soil and the plots were irrigated lightly. Farm yard manure was applied to soil at the time of land preparation. Phosphorous, potassium and nitrogen was applied in the form of DAP, Murate of potash and urea at the rate of 40:40:30 NPK kg/ha respectively. The experimental plots were provided with the calculated quantity of fertilizers. Half dose of nitrogen and full dose of phosphorous and potassium was supplied as basal dose at the time of sowing. The remaining $50 \%$ of nitrogen was given as top dressing at 30 days after sowing. Observations on growth and yield parameters were recorded using five plants per plot selected randomly by avoiding the border plants. The observations on growth parameters were recorded at 30,60 and 90 days after sowing and at the time of harvest. The various observations recorded are mentioned here under. Five plants were selected at randomly from each plot and labelled for recording the data. The following observations were recorded and their mean values were calculated by standard statistical analysis.

Table 1: Effect of integrated nutrient management on different growth stages of fenugreek.

\begin{tabular}{|c|c|c|c|c|c|c|c|c|c|c|c|c|}
\hline \multirow[t]{2}{*}{ Treatment } & \multicolumn{3}{|c|}{$\begin{array}{c}\text { Plant Height } \\
(\mathrm{cm})\end{array}$} & \multicolumn{3}{|c|}{$\begin{array}{c}\text { Number of primary } \\
\text { Branches }\end{array}$} & \multicolumn{2}{|c|}{$\begin{array}{c}\text { Number of } \\
\text { secondary Branches }\end{array}$} & \multirow{2}{*}{$\begin{array}{c}\begin{array}{c}\text { Length of } \\
\text { internode }(\mathrm{cm})\end{array} \\
\end{array}$} & \multirow[t]{2}{*}{$\begin{array}{c}\text { Days to } 50 \% \\
\text { flowering }\end{array}$} & \multirow[t]{2}{*}{$\begin{array}{c}\text { Fresh weight of } \\
\text { the plant }(\mathrm{g})\end{array}$} & \multirow[t]{2}{*}{$\begin{array}{l}\text { Dry weight of } \\
\text { the plant (g) }\end{array}$} \\
\hline & 30 & \begin{tabular}{|l|}
60 \\
\end{tabular} & 90 & 30 & 60 & 90 & 60 & 90 & & & & \\
\hline $\mathrm{T}_{0}$ & 12.86 & 34.20 & 46.68 & 3.39 & 5.19 & 5.46 & 9.97 & 14.93 & 2.42 & 42.50 & 46.86 & 6.90 \\
\hline $\mathrm{T}_{1}$ & 14.62 & 41.89 & 54.22 & 3.83 & 6.13 & 6.36 & 10.87 & 15.68 & 3.18 & 41.00 & 48.57 & 8.92 \\
\hline $\mathrm{T}_{2}$ & 12.15 & 32.98 & 45.32 & 3.39 & 4.96 & 5.23 & 9.77 & 14.93 & 2.27 & 42.17 & 46.21 & 6.43 \\
\hline $\mathrm{T}_{3}$ & 11.86 & 28.88 & 41.77 & 3.26 & 4.86 & 5.16 & 9.70 & 14.60 & 2.09 & 45.67 & 44.48 & 6.14 \\
\hline $\mathrm{T}_{4}$ & 13.52 & 37.42 & 49.75 & 3.59 & 5.53 & 5.89 & 10.23 & 15.00 & 2.77 & 45.00 & 47.66 & 7.82 \\
\hline $\mathrm{T}_{5}$ & 13.44 & 34.97 & 47.35 & 3.49 & 5.53 & 5.79 & 10.17 & 15.00 & 2.68 & 44.00 & 47.47 & 7.44 \\
\hline $\mathrm{T}_{6}$ & 14.54 & 40.74 & 53.42 & 3.73 & 5.86 & 6.13 & 10.70 & 15.46 & 2.95 & 42.97 & 48.22 & 8.19 \\
\hline $\mathrm{T}_{7}$ & 14.57 & 41.37 & 53.69 & 3.73 & 6.09 & 6.19 & 10.73 & 15.52 & 3.08 & 42.03 & 48.41 & 8.42 \\
\hline $\mathrm{T}_{8}$ & 12.86 & 34.26 & 46.68 & 3.39 & 5.49 & 5.79 & 10.10 & 15.00 & 2.55 & 45.17 & 47.14 & 6.92 \\
\hline $\mathrm{T}_{9}$ & 13.70 & 39.37 & 51.70 & 3.36 & 5.63 & 5.96 & 10.30 & 15.06 & 2.81 & 44.33 & 47.88 & 7.98 \\
\hline $\mathrm{T}_{10}$ & 14.49 & 40.14 & 52.48 & 3.36 & 5.79 & 6.06 & 10.37 & 15.46 & 2.91 & 42.73 & 48.03 & 8.16 \\
\hline $\mathrm{T}_{11}$ & 14.63 & 42.24 & 54.57 & 4.09 & 6.36 & 6.56 & 10.93 & 15.78 & 3.82 & 40.70 & 49.07 & 8.99 \\
\hline S.Em. \pm & 0.04 & 0.12 & 0.12 & 0.07 & 0.014 & 0.014 & 0.01 & 0.016 & 0.0132 & 0.70 & 0.4346 & 0.545 \\
\hline $\mathrm{CD}$ at $5 \%$ & 0.11 & 0.36 & 0.35 & 0.018 & 0.039 & 0.037 & 0.04 & 0.05 & 0.0387 & 2.05 & 1.2745 & 1.598 \\
\hline
\end{tabular}

Table 2: Effect of integrated nutrient management on different yield stages of fenugreek.

\begin{tabular}{|c|c|c|c|c|c|c|c|c|c|c|c|c|}
\hline Treatment & $\begin{array}{c}\text { Days to first } \\
\text { pod } \\
\text { formation }\end{array}$ & $\begin{array}{c}\text { Days to } \\
50 \% \text { pod } \\
\text { formation }\end{array}$ & $\begin{array}{c}\text { Number of } \\
\text { pods per } \\
\text { plant }\end{array}$ & $\begin{array}{l}\text { Weight } \\
\text { of pod } \\
(\mathrm{g}) / \mathrm{pod}\end{array}$ & $\begin{array}{c}\text { Pod } \\
\text { length } \\
(\mathrm{cm}) \text { at } \\
\text { harvest }\end{array}$ & $\begin{array}{l}\text { Number } \\
\text { of seeds } \\
\text { per pod }\end{array}$ & $\begin{array}{c}\text { Weight of } \\
\text { seeds per } \\
\text { pod }(\mathrm{g})\end{array}$ & $\begin{array}{c}\text { Seed } \\
\text { yield per } \\
\text { plant (g) }\end{array}$ & $\begin{array}{c}\text { Seed } \\
\text { yield per } \\
\text { plot }(\mathrm{g})\end{array}$ & $\begin{array}{l}\text { Seed } \\
\text { yield } \\
\text { q/ha }\end{array}$ & $\begin{array}{c}\text { Harvest } \\
\text { index } \\
(\%)\end{array}$ & $\begin{array}{c}\text { Days taken } \\
\text { to maturity } \\
\text { (Days) }\end{array}$ \\
\hline $\mathrm{T}_{0}$ & 51.24 & 61.60 & 32.87 & 3.40 & 10.45 & 16.65 & 0.11 & 3.63 & 653.13 & 14.51 & 30.95 & 133.67 \\
\hline $\mathrm{T}_{1}$ & 51.13 & 61.23 & 48.63 & 5.44 & 14.40 & 20.55 & 0.13 & 6.17 & 1111.24 & 24.69 & 39.66 & 119.12 \\
\hline $\mathrm{T}_{2}$ & 51.80 & 62.00 & 30.41 & 3.19 & 9.79 & 12.50 & 0.09 & 2.63 & 472.67 & 10.50 & 22.43 & 128.33 \\
\hline $\mathrm{T}_{3}$ & 55.77 & 65.60 & 25.30 & 2.78 & 8.94 & 13.20 & 0.10 & 2.62 & 471.87 & 10.49 & 24.43 & 123.33 \\
\hline $\mathrm{T}_{4}$ & 52.77 & 62.57 & 38.29 & 3.81 & 11.33 & 17.51 & 0.11 & 4.09 & 736.87 & 16.37 & 31.74 & 130.10 \\
\hline $\mathrm{T}_{5}$ & 53.40 & 63.33 & 37.68 & 3.81 & 11.04 & 17.23 & 0.10 & 3.89 & 700.29 & 15.56 & 31.99 & 124.33 \\
\hline $\mathrm{T}_{6}$ & 54.00 & 63.73 & 44.53 & 4.42 & 13.73 & 19.89 & 0.12 & 5.17 & 931.02 & 20.69 & 35.71 & 129.00 \\
\hline
\end{tabular}




\begin{tabular}{|c|c|c|c|c|c|c|c|c|c|c|c|c|}
\hline $\mathrm{T}_{7}$ & 54.57 & 62.73 & 47.29 & 4.93 & 14.21 & 20.36 & 0.12 & 5.84 & 1051.31 & 23.36 & 37.68 & 131.00 \\
\hline $\mathrm{T}_{8}$ & 55.13 & 61.97 & 33.18 & 3.40 & 10.56 & 16.75 & 0.09 & 3.01 & 542.69 & 12.06 & 25.46 & 125.67 \\
\hline $\mathrm{T}_{9}$ & 55.63 & 62.67 & 41.67 & 4.32 & 11.71 & 17.89 & 0.11 & 4.72 & 849.62 & 18.88 & 34.09 & 127.00 \\
\hline $\mathrm{T}_{10}$ & 52.13 & 63.13 & 43.82 & 4.42 & 12.67 & 18.84 & 0.12 & 5.11 & 919.09 & 20.42 & 35.65 & 126.33 \\
\hline $\mathrm{T}_{11}$ & 50.87 & 60.73 & 50.00 & 5.65 & 14.88 & 21.03 & 0.14 & 6.90 & 1242.82 & 27.62 & 40.59 & 121.11 \\
\hline S.Em. \pm & 0.33 & 0.73 & 0.9027 & 0.0325 & 0.0426 & 0.0788 & 0.0054 & 0.2526 & 45.5 & 1.011 & 1.854 & 3.205 \\
\hline CD at 5\% & 0.96 & 2.14 & 2.6474 & 0.0955 & 0.1251 & 0.2311 & 0.0157 & 0.7410 & 133.8 & 2.96 & 5.438 & 9.399 \\
\hline
\end{tabular}

Table 3: Effect of integrated nutrient management on economics of different treatments of fenugreek.

\begin{tabular}{|c|c|c|c|c|c|c|c|}
\hline Treatment & Treatment Cost & Common Cost & Total cost & Yield /ha & Gross return $\left(\right.$ Rs ha $\left.^{-1}\right)$ & Net return $\left(\right.$ Rsha $\left.^{-1}\right)$ & B: C Ratio \\
\hline $\mathrm{T}_{0}$ & 3276 & 10530 & 13806 & 14.51 & 65295 & 51489 & 3.72 \\
\hline $\mathrm{T}_{1}$ & 9276 & 10530 & 19806 & 24.69 & 111105 & 91299 & 4.60 \\
\hline $\mathrm{T}_{2}$ & 8457 & 10530 & 18987 & 10.5 & 47250 & 28263 & 1.48 \\
\hline $\mathrm{T}_{3}$ & 7638 & 10530 & 18168 & 10.49 & 47205 & 29037 & 1.59 \\
\hline $\mathrm{T}_{4}$ & 24457 & 10530 & 34987 & 16.37 & 73665 & 38678 & 1.10 \\
\hline $\mathrm{T}_{5}$ & 27638 & 10530 & 38168 & 15.56 & 70020 & 31852 & 0.83 \\
\hline $\mathrm{T}_{6}$ & 28457 & 10530 & 38987 & 20.69 & 93105 & 54138 & 1.38 \\
\hline $\mathrm{T}_{7}$ & 37638 & 10530 & 48168 & 23.36 & 105120 & 56952 & 1.18 \\
\hline $\mathrm{T}_{8}$ & 32457 & 10530 & 42987 & 12.06 & 54270 & 11283 & 0.26 \\
\hline $\mathrm{T}_{9}$ & 55638 & 10530 & 66168 & 18.88 & 84960 & 18792 & 0.28 \\
\hline $\mathrm{T}_{10}$ & 20457 & 10530 & 30987 & 20.42 & 91890 & 60903 & 1.96 \\
\hline $\mathrm{T}_{11}$ & 31638 & 10530 & 42168 & 27.62 & 124290 & 82122 & 1.94 \\
\hline
\end{tabular}

\section{Result and Discussion}

In this chapter an attempt has been made to evaluate the possible reasons of the variability obtained due to treatment differences in the present investigation entitled "Study the effect of integrated nutrient management on fenugreek (Trigonella foenum-graecum L.)" The findings described in the preceding chapter have been critically discussed here in detail. The results of the present investigation are discussed in the light of available literature.

\section{Growth parameter of fenugreek}

The result as reported in the preceding chapter revealed integrated nutrient management significantly influenced all the growth attributes.

At 30, 60, and 90 DAS, Application of 50\% RDF + Neem cake@ 1 ton $\mathrm{ha}^{-1}+$ Rhizobium + PSB $\left(\mathrm{T}_{11}\right)$ recorded maximum plant height, while minimum plant height was recorded under the treatment $\left(\mathrm{T}_{3}\right) 50 \% \mathrm{RDF}+$ Rhizobium + PSB. The increase in height of plant is due to the rapid availability of nutrients though chemical fertilizers application and more nitrogen fixation by bacteria which in turn helped in better absorption and subsequent utilization of nitrogen for synthesis of chlorophyll, as nitrogen is an integral part of chlorophyll results in higher photosynthesis there by producing more photosynthesis leading to more plant height by exerting synergistic effect by organic, inorganic and biofertilizers. These results are in accordance with the findings of Jain et al. (2003) [9], Bhunia et al. (2006) ${ }^{[1]}$, Mehta et al. (2012) ${ }^{[12]}$ and Rizvi et al. (2013) ${ }^{[8]}$ in fenugreek. Rhizobium lives in root hairs of the legumes forming root nodules, where it fixes atmospheric nitrogen which is the major nutrient available for the growth of the plant the synergistic effect of Rhizobium as well as Neem cake which is having the nitrification regulative property resulted in increased vegetative growth (Singhal and Mudgal, 1982) ${ }^{[24]}$. The results of the investigation are in agreement with the findings of Verma et al. (1991) ${ }^{[26]}$, Purbey and Sen (2005) ${ }^{[7]}$, Singh et al. (2010) ${ }^{[9]}$ in fenugreek.

Early flowering was observed under the treatment $\left(\mathrm{T}_{11}\right) 50 \%$ $\mathrm{RDF}+$ Neem cake @ 1 ton ha ${ }^{-1}+$ Rhizobium + PSB, while late flowering was observed under the treatment $\left(\mathrm{T}_{3}\right) 50 \%$ $\mathrm{RDF}+$ Rhizobium + PSB. The early flowering was due to sufficient balanced vegetative growth and availability of certain micronutrients with higher doses of organic manures in combination of inorganic fertilizers led the plants to enter into reproductive phase early as reported by Umesha et al. (2011) ${ }^{[25]}$ in Makoi. Whereas, plants supplied with lower doses of organic manures, with low supply of nutrients for their growth resulted in reduced growth and delayed flowering. These results are in agreement with the findings of Gizaway et al. (1992) ${ }^{[7]}$ in spinach, Mandal and Maiti (1992) ${ }^{[13]}$, Kaswan et al. (1995) ${ }^{[10]}$, Jagdale and Dalve (2010) ${ }^{[8]}$ and Bommi et al. (2010) [3] in fenugreek and Renuka and Ravishankar (2001) ${ }^{[20]}$ in tomato.

The maximum number of primary branches of per plant at 30 , 60 and 90 DAS, Secondary branches per plant at 60and 90 DAS, length of internodes, fresh weight of plant and dry weight of plant, was recorded in treatment $\left(\mathrm{T}_{11}\right) 50 \% \mathrm{RDF}+$ Neem cake @ 1 ton $\mathrm{ha}^{-1}+$ Rhizobium + PSB, wheras it was recorded minimum under the treatment $\left(\mathrm{T}_{3}\right) 50 \% \mathrm{RDF}+$ Rhizobium + PSB. This might be due to the source of organic manures and inorganic sources of nutrients ensured readily available nutrients for initial requirement though inorganic source and longer period availability though organic source. Bio-fertilizers improves root nodulation and provided the congenial soil environment for plant rhizosphere increases nitrogen fixation and phosphorous solubilization, increased more growth there by increased number of primary branches per plant, secondary branches per plant at 60 and 90 DAS, length of internodes, fresh weight of the plant and dry weight of the plant. Increase in the plant spread per branching might be due to organic manures along with inorganic fertilizers not only supply major nutrients but also sufficient quantity of required micro nutrients and minerals besides, the biofertilizers which have the ability to mobilize the nutritionally important elements from non usable from to usable from. Use of bio-fertilizers creates the favorable environment in rhizosphere, increased the microbial population at tremendous rate. The decomposed organic matter in the soil and biological nitrogen fixation though bio-fertilizers and subsequent release of nitrogen increased the growth. The continuous availability of nutrients resulted in more nutrient uptake by plant ensures more dry matter accumulation at all growth stages. Similar combined beneficial effect of organic manures, inorganic fertilizers and bio-fertilizers on growth parameters was recorded by Singh and Verma (2002) ${ }^{[23]}$ in French bean, 
Bhunia et al. (2006) ${ }^{[1]}$ in fenugreek, Bahadur et al. (2004) ${ }^{[2]}$ in cabbage, Pawan et al. (2006) ${ }^{[16]}$ in okra, Chand et al. (2001) [4] in Mentha arvensis, Kumarvel (2003) ${ }^{[12] ~ i n ~}$ Artemesia annua, Umesha et al. (2011) [25] in Makoi, Choudhary et al. (2011) ${ }^{[2]}$ in fenugreek, Singh and Verma (2002) ${ }^{[23]}$ in French bean and Das et al. (2012) ${ }^{[6]}$ in Senna.

\section{Yield parameters}

The minimum days to first pod formation and days to $50 \%$ pod formation was recorded under treatment $\left(\mathrm{T}_{11}\right) 50 \% \mathrm{RDF}$ + Neem cake @ 1 ton ha $^{-1}+$ Rhizobium + PSB, while the maximum days to pod formation and days to $50 \%$ pod formation was recorded in $\left(\mathrm{T}_{3}\right) 50 \% \mathrm{RDF}+$ Rhizobium + PSB. The early pod formation might be due to sufficient vegetative growth with balanced doses of organic manures along with inorganic fertilizers which made the plants to enter into reproductive phase early and made the flower to mature early and resulted in early pod formation. These results are in agreement with the findings of Renuka and Ravishankar (2001) ${ }^{[20]}$ in tomato. Further, the lower doses of inorganic manures significantly taken minimum period for first pod appearance and these results are in conformity with Mandal and Maiti (1992) ${ }^{[13]}$, Kaswan et al. (1995) ${ }^{[10]}$ and Jagdale and Dalve (2010) ${ }^{[8]}$ in fenugreek

Maximum number of pods per plant, weight of pod per plant and length of pod per plant was recorded under treatment ( $\left.\mathrm{T}_{11}\right) 50 \% \mathrm{RDF}+$ Neem cake @ 1 ton $\mathrm{ha}^{-1}+$ Rhizobium + PSB, while the minimum number of pods per plant, weight of pod per plant and length of pod per plant was recorded in $\left(\mathrm{T}_{3}\right)$ $50 \%$ RDF + Rhizobium + PSB. The higher number of pods per plant, weight of pod per plant and length of pod per plant might be due to the available nitrogen in the soil throughout the life cycle of crop. The increased and balanced supply of nitrogen to plant promotes synthesis of more carbohydrates resulted in more flowering, fruiting and partitioning of food material and subsequent distribution from source to sink. The organic manures and bio-fertilizers increase the soil microbial activity, improve the availability of phosphorous and in turn plays unique role in energy conversion and transfer, helpful in flowering and increased the number of pods per plant, weight of pod per plant and length of pod per plant as reported by Khiriya et al. (2003) ${ }^{[11]}$ and Choudhary et al. (2011) ${ }^{[2]}$ in fenugreek.

Maximum number of seeds per pod, weight of seed per pod and harvest index $\%$ was recorded under treatment $\left(\mathrm{T}_{11}\right) 50 \%$ RDF + Neem cake@1 ton ha ${ }^{-1}+$ Rhizobium + PSB, While the minimum number of seeds per pod, weight of seed per pod and harvest index \% was recorded in $\left(\mathrm{T}_{2}\right) 75 \% \mathrm{RDF}+$ Rhizobium + PSB. This might be due to the combination of organic manures, inorganic fertilizers along with biofertilizers inoculation ensured readily availability of nutrients mainly nitrogen, phosphorous and potassium accelerated the growth of microbial population in rhizosphere which provide the efficient frame work for high rates of nutrient absorption and net assimilation, which are responsible for productive metabolism as stated by Choudhary et al. (2011) ${ }^{\text {[2] in }}$ fenugreek and Rao et al. (2010) ${ }^{[18]}$ in long pepper. The increased availability of all balanced nutrient to plant, promoted the flowering and fruiting. The availability of major nutrients in proportionate amount increases concentration of carbohydrates in seed which serve as a reservoir of carbohydrates,
This might have been resulted in increased number of seeds in each pod and there by increased in weight of seed per pod. Similar results were also observed by Rathore and Manohar (1989), Mandal and Maiti (1992) [13], Kaswan et al. (1995) ${ }^{[10]}$, Singh and Verma (2002) ${ }^{[23]}$, Khiriya et al. (2003) ${ }^{[11]}$ and Choudhary et al. (2011) ${ }^{[2]}$ in fenugreek.

Minimum days taken to maturity were recorded under treatment $\left(\mathrm{T}_{1}\right)$ 100\% RDF (40: 40: $30 \mathrm{~N}, \mathrm{P}_{2} \mathrm{O}_{5}$ and $\mathrm{K}_{2} \mathrm{O}$ and $\mathrm{kg} \mathrm{ha}^{-1}+$ Rhizobium + PSB, while the maximum days taken to maturity were recorded under $\left(\mathrm{T}_{0}\right) 100 \% \mathrm{RDF}$ 40: 40: 30 $\mathrm{N}, \mathrm{P}_{2} \mathrm{O}_{5}$ and $\mathrm{K}_{2} \mathrm{O} \mathrm{kg} \mathrm{ha}{ }^{-1}$.

Maximum seed yield per plant and seed yield $\mathrm{q} / \mathrm{ha}$ was recorded under treatment $\left(\mathrm{T}_{11}\right) 50 \% \mathrm{RDF}+$ Neem cake @ 1 ton $\mathrm{ha}^{-1}+$ Rhizobium $+\mathrm{PSB}$, while the minimum seed yield per plant and seed yield $\mathrm{q} /$ ha was recorded in $\left(\mathrm{T}_{3}\right) 50 \% \mathrm{RDF}+$ Rhizobium + PSB. The increase in seed yield per plant and seed yield $\mathrm{q} / \mathrm{ha}$ might be due to cumulative effect of more grain filling percentage, more number of seeds per pod, weight of seed per pod and length of pod. The increased nutrient uptake by plant might have stimulated the rate of various physiological processes like growth and assimilation by the balanced application of organic and inorganic sources along with bio-fertilizers (Rhizobium + PSB) inoculation. Similar results were reported by Singh and Verma (2002) ${ }^{[23]}$, Khiriya et al. (2003) [11], and Choudhary et al. in fenugreek and Patel et al. (2004) ${ }^{[6]}$ in cumin.

The maximum net profit and $\mathrm{B}: \mathrm{C}$ ratio was obtained under the treatment $\left(\mathrm{T}_{1}\right)$ 100\% RDF (40: 40: $30 \mathrm{~N}, \mathrm{P}_{2} \mathrm{O}_{5}$ and $\mathrm{K}_{2} \mathrm{O}$ kg ha$\left.{ }^{1}\right)+$ Rhizobium + PSB, while the minimum net profit and B: $\mathrm{C}$ : ratio was gained under the treatment $\left(\mathrm{T}_{8}\right) 75 \% \mathrm{RDF}+$ Poultry manure @ 2 ton $\mathrm{ha}^{-1}+$ Rhizobium + PSB.

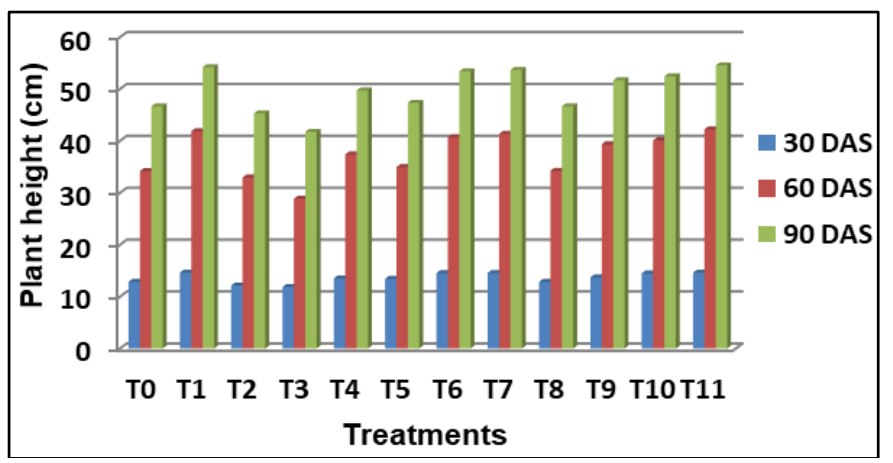

Fig 1: Effect of integrated nutrient management on plant height $(\mathrm{cm})$ at different stages of fenugreek.

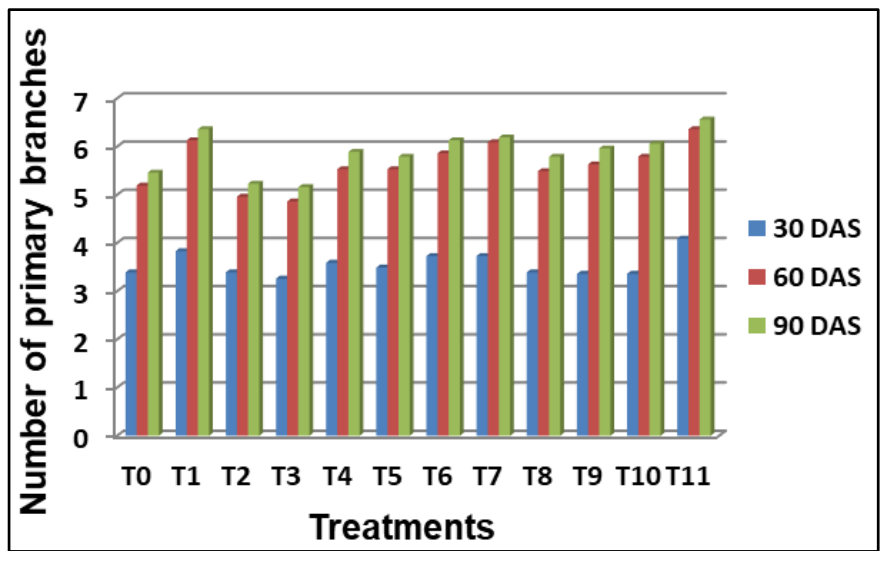

Fig 2: Effect of integrated nutrient management on number of primary branches at different stages of fenugreek. 


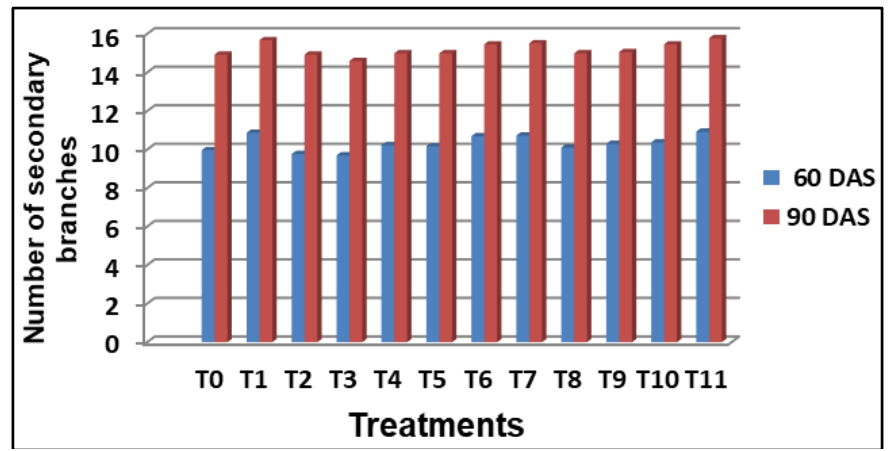

Fig 3: Effect of integrated nutrient management on number of secondary branches at different stages of fenugreek.

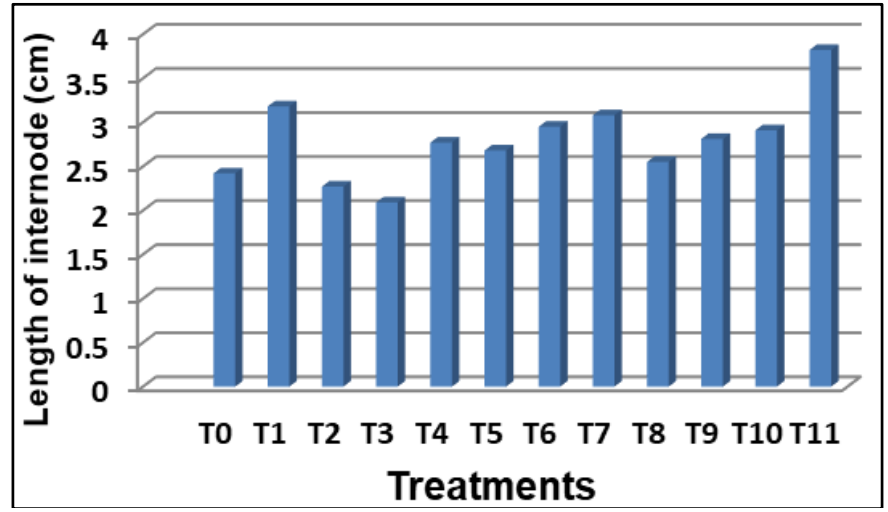

Fig 4: Effect of integrated nutrient management on length of internode $(\mathrm{cm})$ of fenugreek.

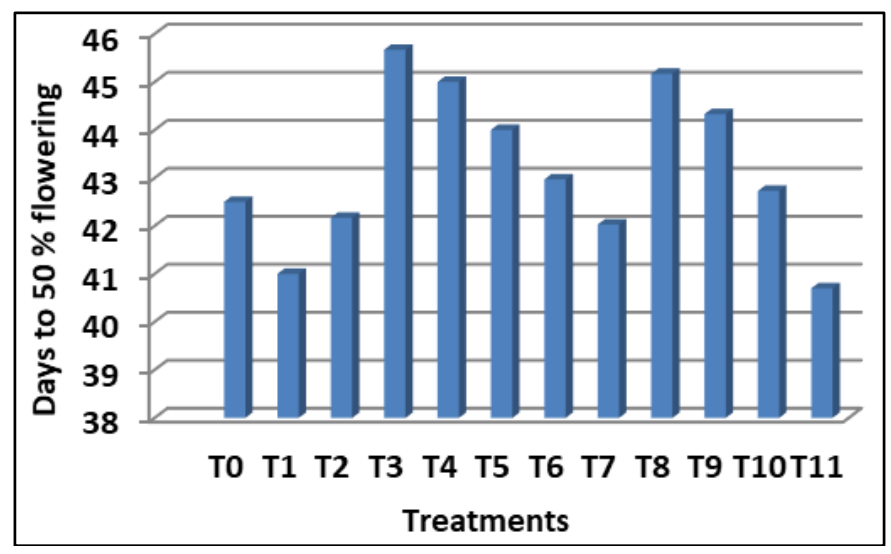

Fig 5: Effect of integrated nutrient management on days to 50\% flowering of fenugreek.

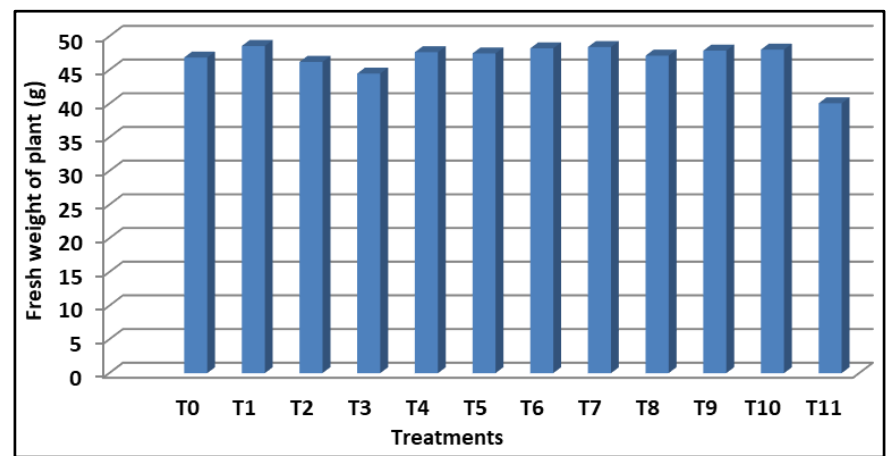

Fig 6: Effect of integrated nutrient management on fresh weight of plant (g) of fenugreek.

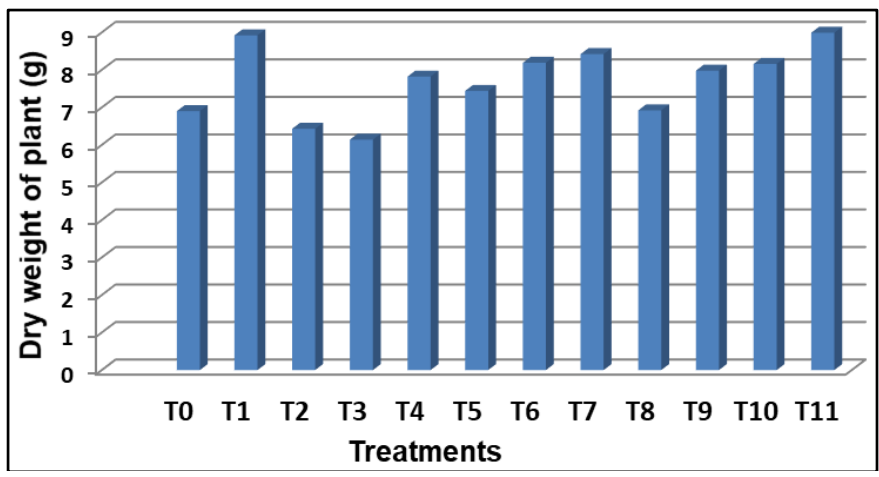

Fig 7: Effect of integrated nutrient management on dry weight of plant (g) of fenugreek.

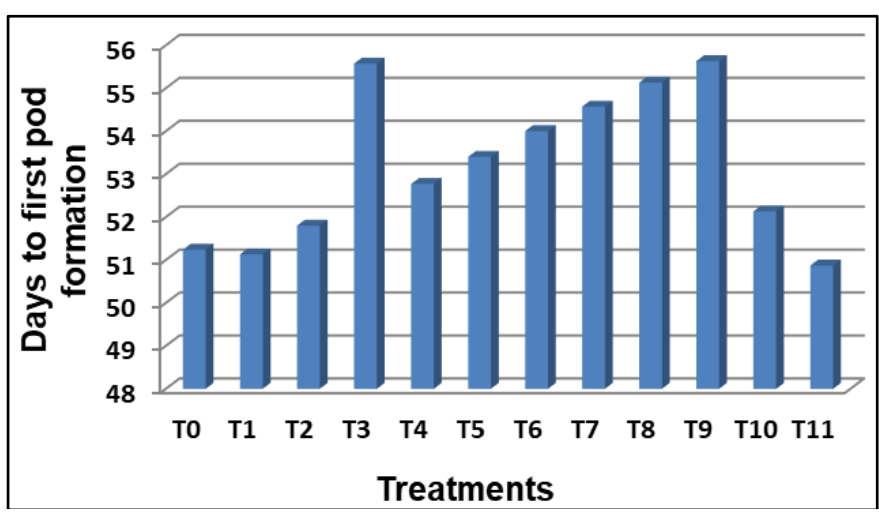

Fig 8: Effect of integrated nutrient management on days to first pod formation of fenugreek.

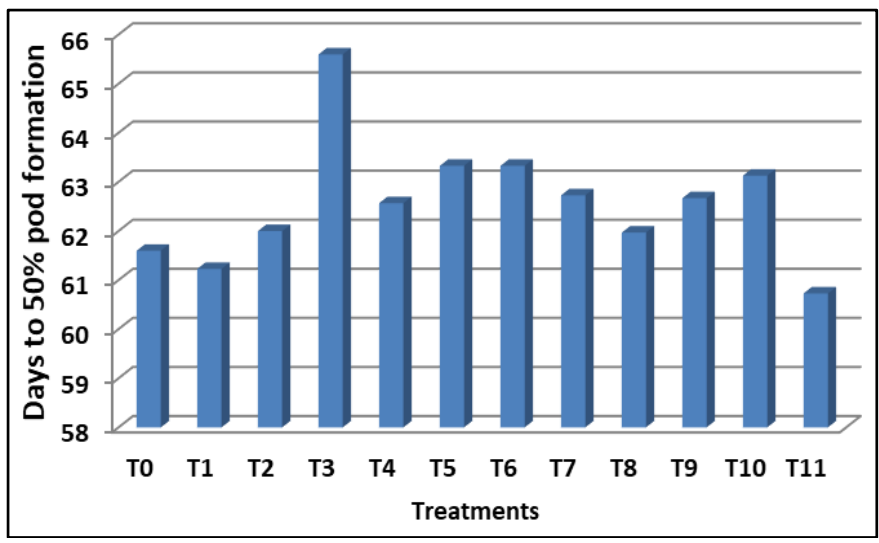

Fig 9: Effect of integrated nutrient management on days to $50 \%$ pod formation of fenugreek.

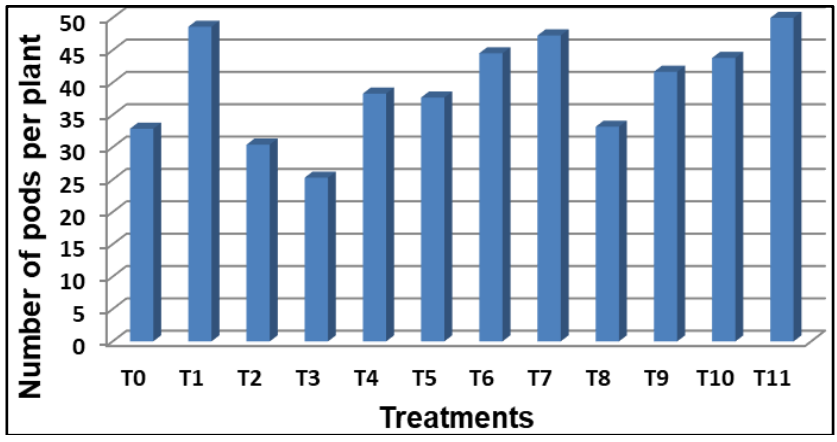

Fig 10: Effect of integrated nutrient management on number of pods per plant of fenugreek. 


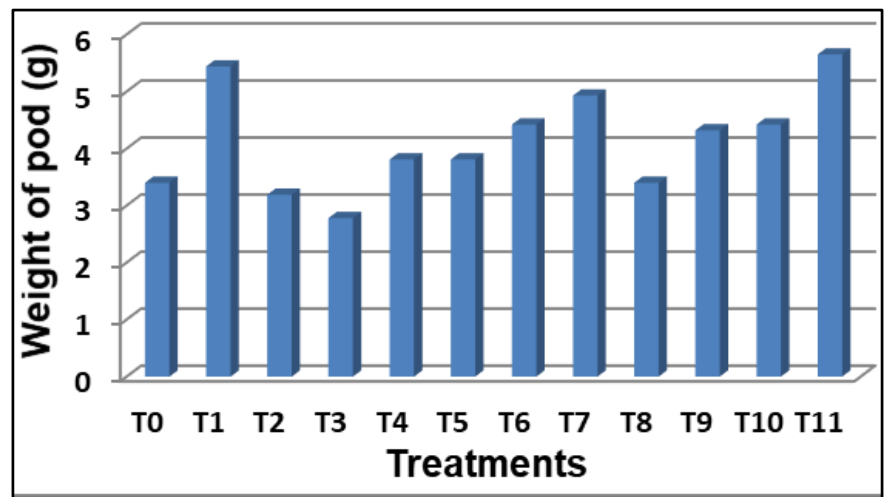

Fig 11: Effect of integrated nutrient management on weight of pod (g) of fenugreek.

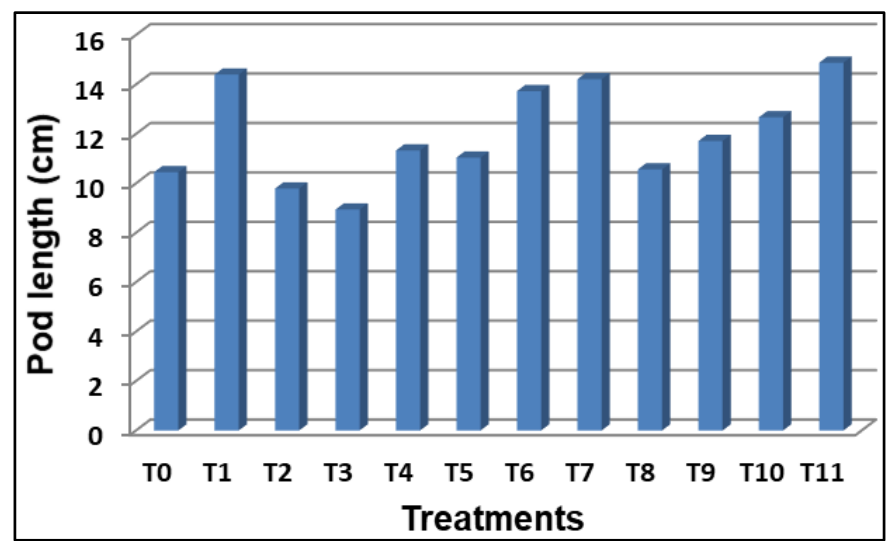

Fig 12: Effect of integrated nutrient management on pod length $(\mathrm{cm})$ at harvest of fenugreek.

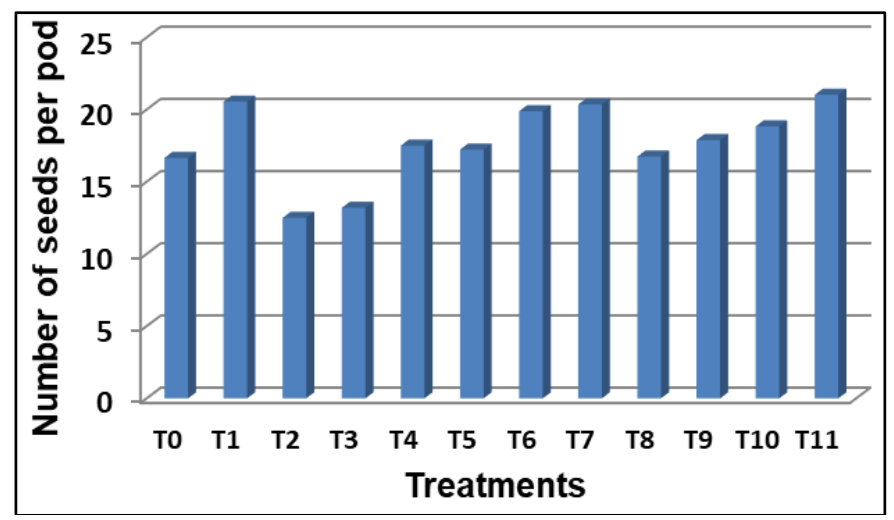

Fig 13: Effect of integrated nutrient management on number of seeds per pod of fenugreek.

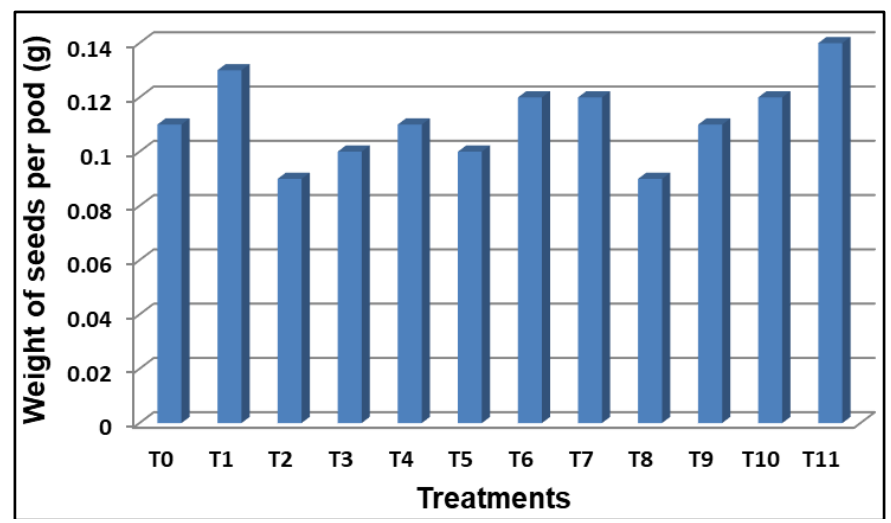

Fig 14: Effect of integrated nutrient management on weight of seeds per pod $(\mathrm{g})$ of fenugreek.

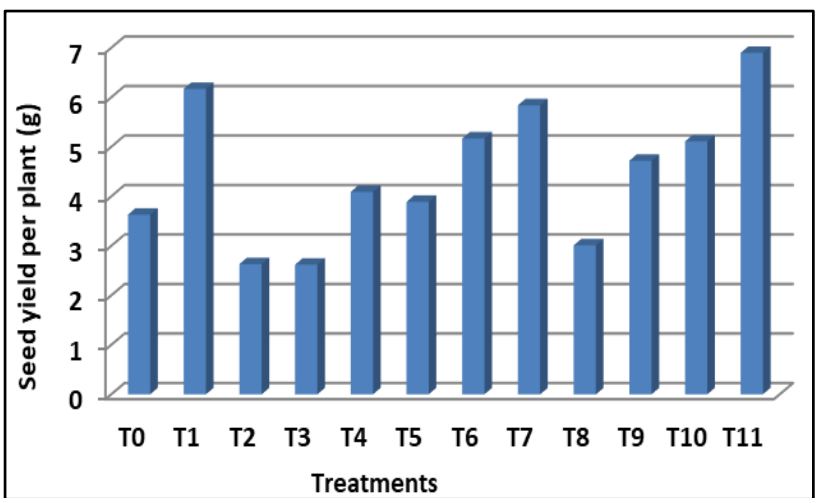

Fig 15: Effect of integrated nutrient management on seed yield per plant $(\mathrm{g})$ of fenugreek.

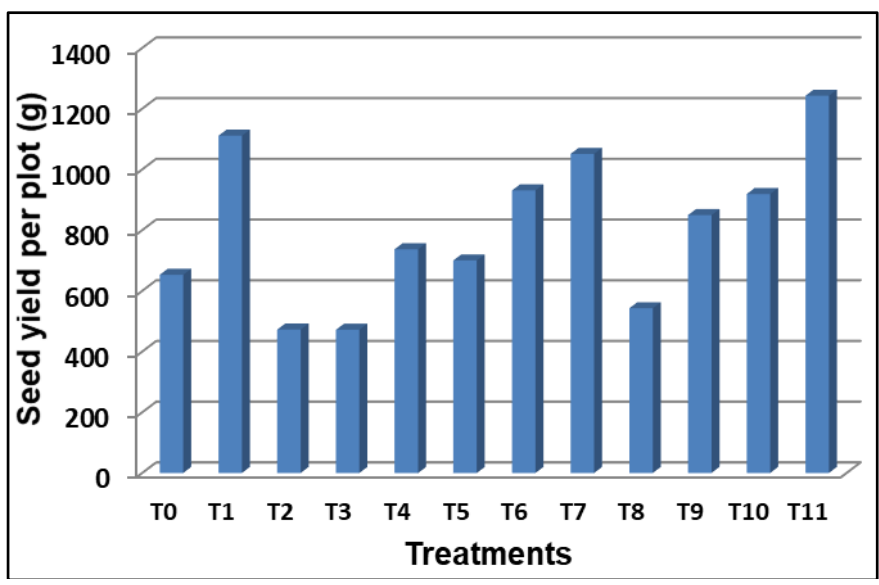

Fig 16: Effect of integrated nutrient management on seed yield per plot $(\mathrm{g})$ of fenugreek.

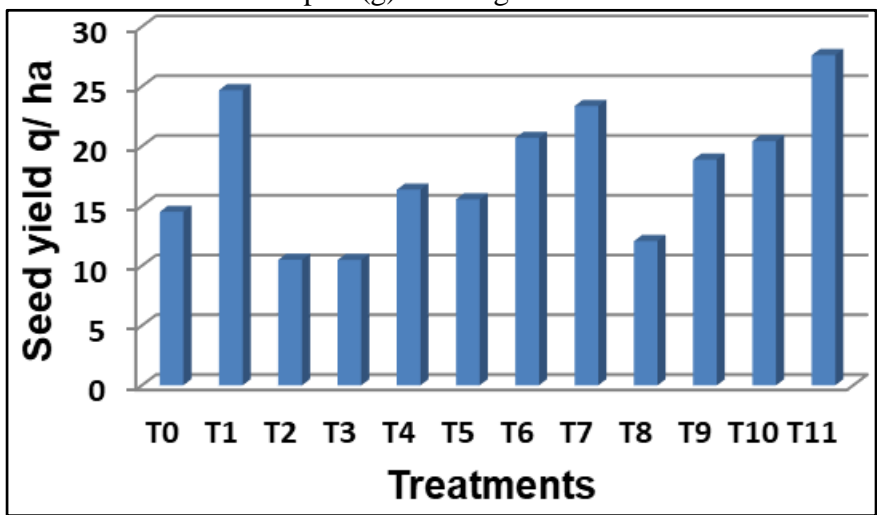

Fig 17: Effect of integrated nutrient management on seed yield q/ha of fenugreek.

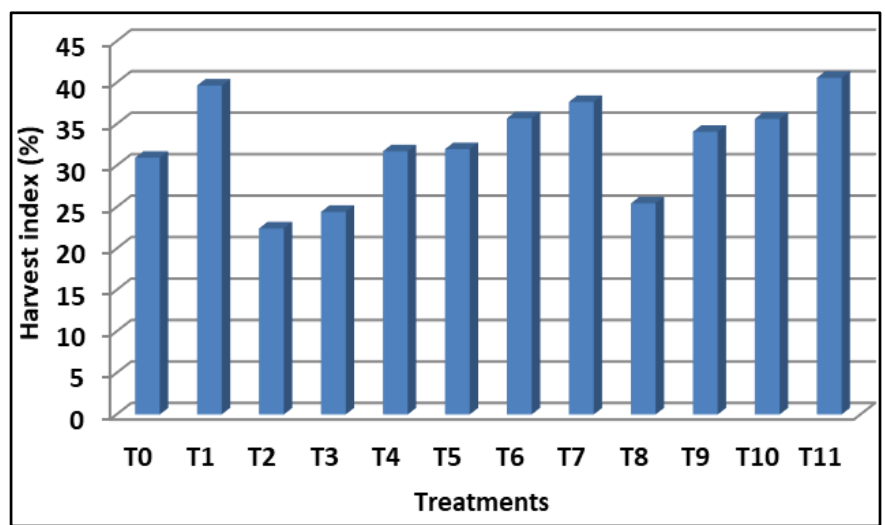

Fig 18: Effect of integrated nutrient management on harvest index $(\%)$ of fenugreek. 


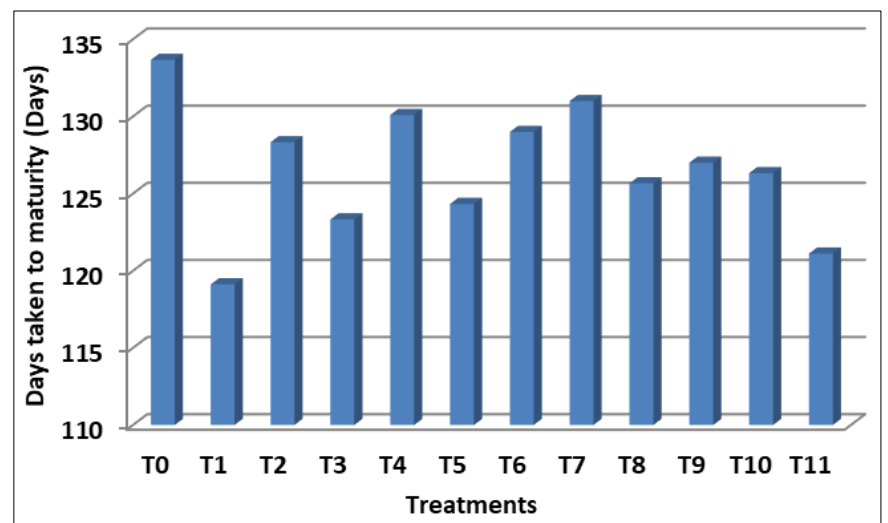

Fig 19: Effect of integrated nutrient management on days taken to maturity (Days) of fenugreek.

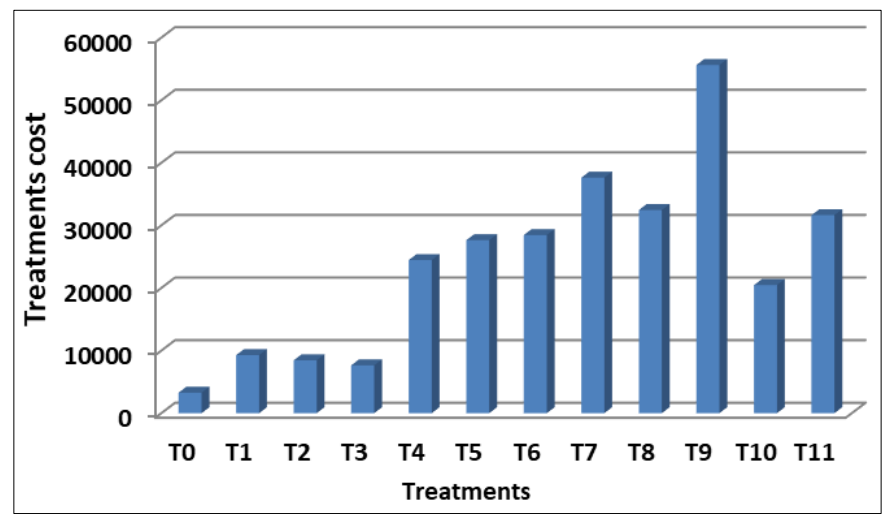

Fig 20: Effect of integrated nutrient management on economics of different treatments cost of fenugreek.

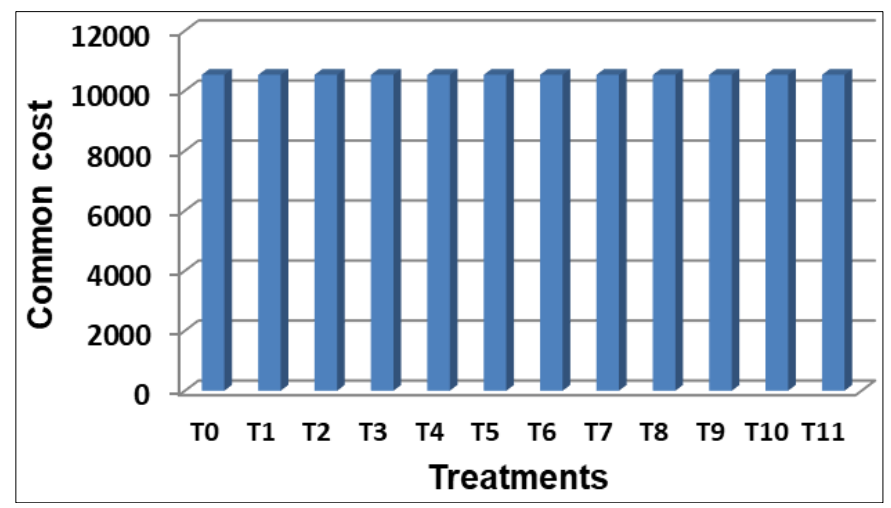

Fig 21: Effect of integrated nutrient management on economics of different common cost of fenugreek.

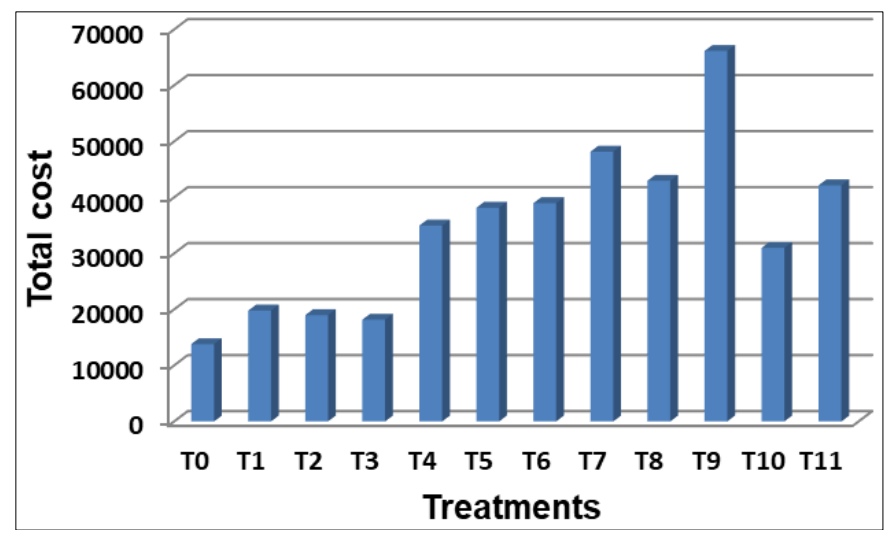

Fig 22: Effect of integrated nutrient management on economics of different total cost of fenugreek.

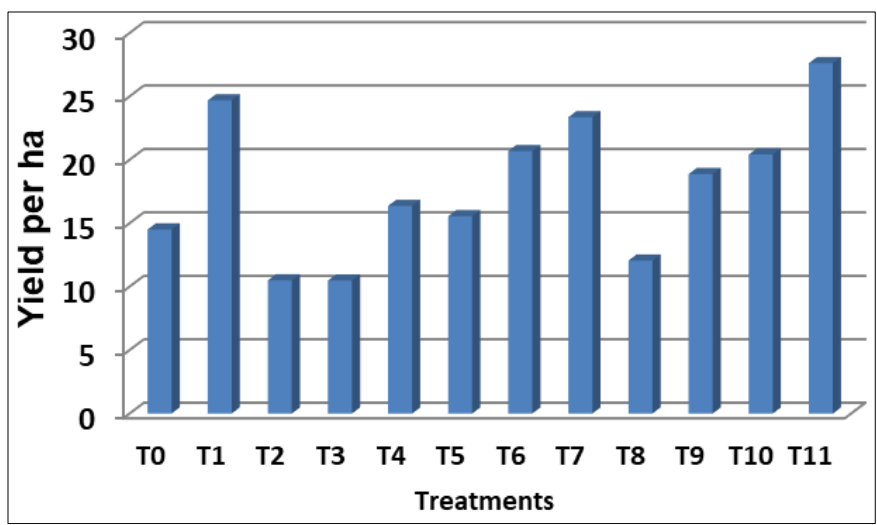

Fig 23: Effect of integrated nutrient management on economics of different treatments of seed yield per ha of fenugreek.

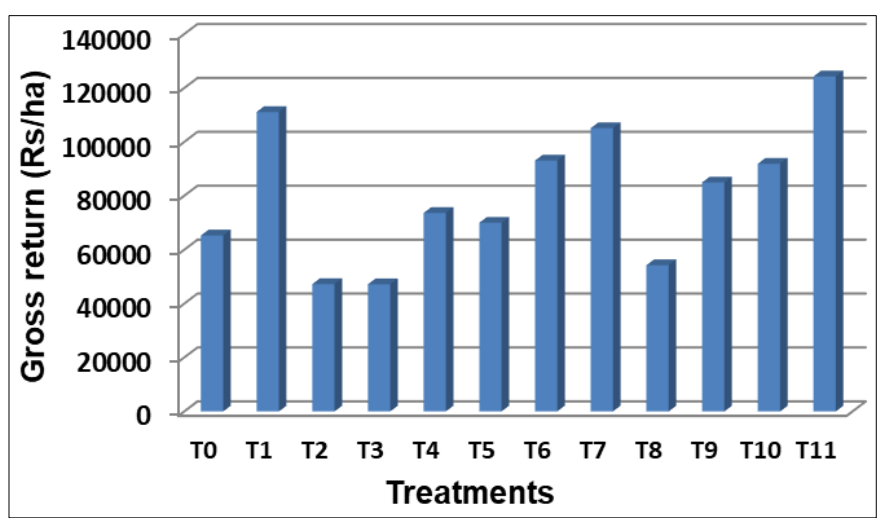

Fig 24: Effect of integrated nutrient management on economics of different gross return (Rs/ha) of fenugreek.

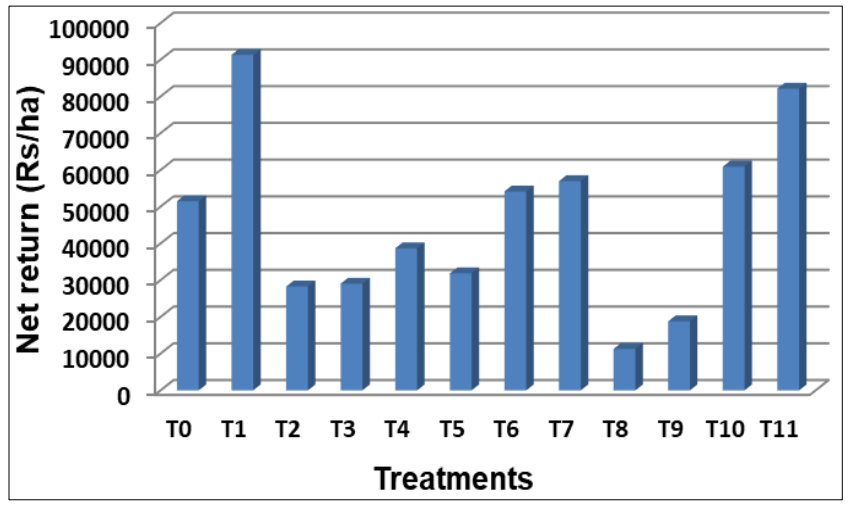

Fig 25: Effect of integrated nutrient management on economics of different net return $(\mathrm{Rs} / \mathrm{ha})$ of fenugreek.

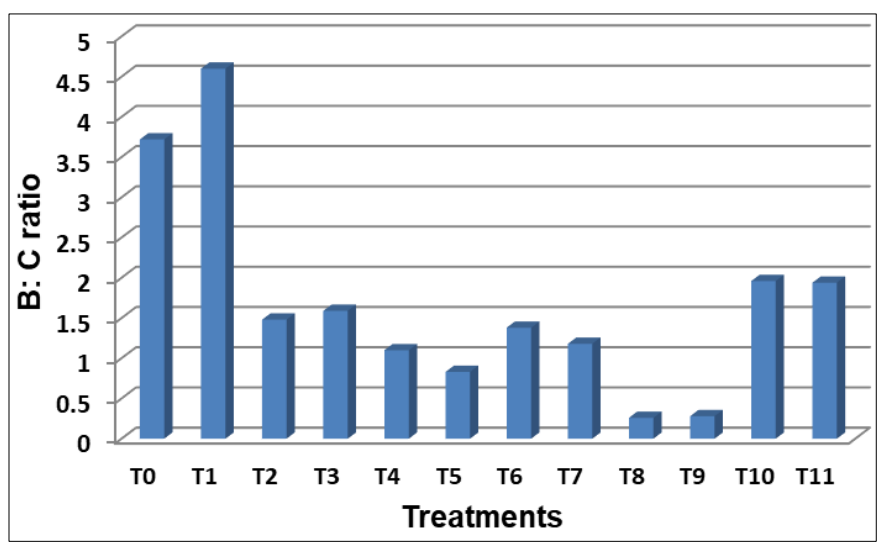

Fig 26: Effect of integrated nutrient management on economics of different treatments B: C ratio of fenugreek. 


\section{Conclusions}

The present investigation entitled "Study the effect of integrated nutrient managementon fenugreek (Trigonella foenum-graecum L.)" was conducted during the period from October 2016 to March 2017 at the Department of Plantation, Spices, Medicinal and Aromatic Crops, College of Horticulture, Mandsaur, Rajmata Vijayaraje Scindia Krishi Vishwa Vidyalaya, Gwalior (M.P.).

The experiment was laid out in Randomized Block Design with three replications. Fenugreek cultivar AFG-3was used for the experiment. Twelve treatments consisting of integrated nutrient management with organic, inorganic and biofertilizers along with control. The observations on different growth and yield parameters were recorded and the results obtained are summarized below. On the basis of one year research trial it could be concluded that the treatment $\left(\mathrm{T}_{11}\right)$ i.e. $50 \%$ RDF + Neem cake @ 1 ton ha $^{-1}+$ Rhizobium + PSB was best at all the stages of growth parameters like plant height 30,60 and 90 das $(\mathrm{cm})$, number of primary branches per plant at 30, 60 and 90 DAS, number of secondary branches per plant at 60 and 90 DAS, length of internode, days to $50 \%$ flowering, fresh and dry weight of the plants and yield parameters like days to first pod formation, days to $50 \%$ pod formation, number of pods per plant, weight of pod, pod length at number of seeds per pod, weight of seeds per pod, seed yield per plant, seed yield $\left(\mathrm{q} \mathrm{ha} \mathrm{h}^{-1}\right)$, harvest index and days taken to maturity showed better performance from other treatments of organic, inorganic and biofertilizers applications.

\section{References}

1. Bhunia SR, Chauha RPS, Yadav BS, Bhati AS. Effect of phosphorous, irrigation and rhizobium on productivity, water use and nutrient uptake in fenugreek (Trigonella foenum-graecum L.). Indian J Agro. 2006; 51:239-241.

2. Bahadur A, Singh KP, Upadhayay AK, Rai M. Effect of organic amendments and biofertilizers on growth, yield and quality attributes of Chinese cabbage (Brassica pekinensis). Indian Journal of Horticulture. 2004; 76:596598.

3. Bommi PV, Jinturkar SP, Bhosle AM, Noor S. Effect of graded levels of nitrogen and seed rate on growth and flowering of fenugreek (Trigonella foenum-graecum L.) cv. RMT-1. The Asian Journal of Horticulture. 2010; 5(2):491-494.

4. Chand S, Anwer M, Patra DD. Influence of combined application of farmyard manure and Inorganic fertilizers on herb, essential oil and nutrient accumulation in menthol mint (Mentha arvensis). Journal of medicinal and aromatic plant Sciences. 2001; 23:29-33.

5. Choudhary BR, Gupta AK, Parihar CM, Jat SL, Singh DK. Effect of integrated nutrient management on fenugreek (Trigonella foenum-graecum) and its residual effect on fodder pearl millet (Pennisetum glaucum). Indian J Agro. 2011; 56(3):189-195.

6. Das B, Reddy GS, Kayina A. Effect of organic manures, biofertilizers and inorganic fertilizers on growth and yield of Senna (Cassia angustifolia Vahi.). The Asian Journal of Horticulture. 2012; 7(1):144-147.

7. Gizaway AM, Oksh I, Sharaf A, Nabar. Effect of sowing dates, rate and number of nitrogen application on spinach flowering and seed yield. Annals Agricultural Sciences. Egypt. 1992; 37(1):159-166.

8. Jagdale YL, Dalve PD. Effect of nitrogen and phosphorus levels on growth, flowering and pod formation of fenugreek. The Asian Journal of Horticulture. 2010; 5(2):301-304.

9. Jain LK, Singh P, Singh P. Growth and nutrient uptake of chickpea (Cicer arietinum L.) as influenced by biofertilizer and phosphorous nutrition. Crop Research. 2003; 25:410-413.

10. Kaswan MP, Singh GR, Mangal JL. Effect of nitrogen and cuttings on growth, flowering, pod development and seed maturity of fenugreek Cultivers. Haryana Journal of Horticultural Sciences. 1995; 24(11):42-45.

11. Khiriya KD, Singh BP, Taneja KD. Effect of farm yard manure and phosphorus levels on yield, quality and nutrient uptake by fenugreek. Forage Research. 2003; 28(4):210-214.

12. Kumaravel. Productivity and quality of Artemisia annua L. Under organic cultivation. M.Sc. thesis, University of Agricultural Sciences, Bengalore, 2003.

13. Mandal AR, Maiti RG. Effect of nitrogen and phosphorous on growth, flowering and seed yield of fenugreek. Indian Agriculture, 1992; 36(3):164-169.

14. Mehta RS, Anwer MM, Malhotra SK. Influence of sheep manure, vermicompost and biofertilizer on growth, yield and profitibility of cumin. (Cuminum cyminum L.) Production. J Spices Aromatic Crops. 2012; 21(1):16-19.

15. Patel BS, Amin AU, Patel KP. Response of cumin (Cuminum cyminum) to integrated nutrient management. Indian J Agro. 2004; 49(3):205-206.

16. Pawan Y, Singh P, Yadav RL. Effect of organic manures and nitrogen levels on growth, yield and quality of okra. Indian journal of Horticulture. 2006; 63:215-217.

17. Purbey SK, Sen NL. Response of fenugreek to bioinoculants and plant bio regulators. Indian J Horti. 2005; 62(4):416-418.

18. Rao GE, Krishna Reddy GS, Vasundhara M, Nuthan D, Manjunatha Reddy K, Prabhu Ganiger C et al. Studies on effect of integrated nutrient management in long pepper (Pipper longum L.). The Asian Journal of Horticulture. 2010; 5(2):359-363.

19. Rathore PS, Manohar SS. Effect of date of sowing, levels of nitrogen and phosphorous on quality and nodulation of fenugreek. Indian Cocoa-Areca nut \& Spices Journal. 1989; 13(4):148.

20. Renuka B, Ravishankar C. Effect of organic manures on growth and yield of Tomato. South Indian Horticulture. 2001; 49:216-220.

21. Rizvi R, Mahmood I, Tiyagi SA. Potential role of organic matters and phosphate molubilizing bacteria (PSB) on the growth and productivity of fenugreek. J Agric. Sci. Tech. 2013; 15:639-647.

22. Singh AKLY, Singh VB. Effect of INM on yield, quality and uptake of N, P and K by Ginger. Agro. 2010; 20(1):74-79.

23. Singh NB, Verma KK. Response of French bean (Phaseolus vulgaris) to organic and inorganic manures in eastern Uttar Pradesh. Indian Journal of Agronomy. 2002; 47(1):81-85.

24. Singhal KK, Mudgal. Versatile Neem. Agri. Rev. 1982; 4:2-10.

25. Umesha K, Soumya SP, Smitha GR. Seeeramu BS. Influence of organic manures on growth, yield and quality of makoi (Solanum nigrum L.) Indian J. Horti. 2011; 68(2):235-239.

26. Verma JP, Thakur RN, Sharma BN, Katiyar DS, Singh V. Response of fenugreek to nitrogen and phosphorous levels. Indian Journal of Agronomy. 1991; 36(1):116-118. 